\title{
UTILIZING BLOG IN ELT WRITING TO NON-ENGLISH MAJOR UNDERGRADUATE STUDENTS OF WIRALODRA UNIVERSITY
}

\author{
Natalia Anggrarini*1, Atikah Wati" ${ }^{* 2}$ \\ natalia.anggrarini@unwir.ac.id *1, atikah_wati@unwir.ac.id*2 \\ Faculty of Teachers Training and Education Science - English Education Department \\ Wiralodra University
}

\begin{abstract}
Revolutionary Industry 4.0 demands the advanced of technology supports not only in evolutionary level of information and communication, but also in education. Seeking to promote interest of English in higher level of education, this study aims to find out students' experiences in utilizing Blog to learn English especially writing activity. About 15 of Non-English first-grade undergraduate students focusing on Mathematics Education Department voluntary participated in this study. By conducting qualitative research method, questionnaires to 15 students were given to gain the data. The data from questionnaires then be interpreted for the experiences in utilizing blog in English writing activity. The result reveals that blog gave the students a place to share their ideas, exchange ideas, and improve their English as well as their writing ability. Utilizing blog in writing activity also gave them more knowledge about ICT especially in bloging. The findings also lead to some points for the teacher to consider before they utilize blog in writing activity. First, it is about time allocation and second is about involvement of students. The finding also suggest the teacher to provide longer time in doing blog project and big class is needed to have more meaningful interaction in the blog itself.
\end{abstract}

Keywords: Non-English Major Students, Blog, Writing.

\section{INTRODUCTION}

Creating meaningful learning environment is one of Teachers' ability to maintain students' motivation especially in learning English. Adult students in this case college students need interesting and challenging environment to learn English. Teachers should be able to see the possible way to give new experience for the students to learn English as well as to maintain their interest. The expected environment is to give new nuance for adult students by considering what they are mostly engaged in their daily life. One thing the students mostly engaged in their daily life is media social.

This growth of information and technology sets the environment for the students where they can access any kinds of social media to interact or communicate interactively. This opportunity ideally guide them to be well English speakers since the environment offered by web 2.0 gives the strong potential to have social interaction (Ozkan, 2014).

Recent years have been a moment of tremendous explosion of social media (Akcay and Arslan, 2010; Sidek and Yunus, 2011; Ozkan, 2014; Kamberi, 


\section{Natalia Anggrarini ${ }^{* 1}$, Atikah Wati ${ }^{* 2}$ \\ UTILIZING BLOG IN ELT WRITING ACTIVITY TO NON-ENGLISH MAJOR UNDERGRADUATE STUDENTS OF WIRALODRA UNIVERSITY}

2015). This explosion widespreads to all social media, blog is included here. Blog is simple webpage consisting a brief paragraphs of opinion, information, personal diary entries, or links called post arranged chronologically with the most recent first, in the style of an online journal (Barger; Doc et al, as cited in Akcay and Arslan, 2010). With the explosion of social media and its function, no wonder many teachers utilize blogs in their teaching and learning activity. The features of blog allow the students to create paragraphs to build communicative interaction by the features of comment.

As the rapid growth of technology, people tend to utilize social media in any kinds of activity they do. People all over the world are freely to access this media, thus English becomes important for the widespread of information. As written language is mostly used in the social media interaction, many teachers did improvement of writing skills by utilizing social media, such as Blog. Some researchers investigated the benefit of Blog in teaching English especially in teaching writing (Arslan \& Kizil, as cited in Akcay \& Arslan, 2010, Noytim, 2010, Mansor, 2010; Sidek and Yunus, 2011; Ozdemir \& Aydin, 2015). It is found that blogs are helpful in motivating and interesting for the students in writing activity but the interactive communication is not effectively done.

However, experience felt by the students when they learn English writing is less explored. Once explored by Sidek \& Yunus (2011), students enjoyed learning English by using blog for the tools and features available in blog not in term of the writing itself. The result from their study found that blogs is the safe place for the students to explore the students' learning, but the feedback was not effective. Thus in this study provides blog namely nataliaanggrarini.wordpress.com as a space for the students to post their writing. What to be investigated here is the detail experience of the students when they learn writing by utilizing blog.

Thus the research questions of this research are as follow:

1. How was the Blog Project implemented in writing activity?

2. How was the students experience in utilizing blog in writing activity?

3. How was the students' response toward the utilizing blog in writing activity?

\section{LITERATURE REVIEW}

\subsubsection{Weblog-based Learning}

Education move in line with the development of information and technology. In this era, weblog is included into the part of its learning. Web-based technologies and powerful internet connections provide various new possibilities for the development of educational technology (Sarica \& Cavus, 2009). Weblog-based learning is taken from the change of technology based or distance learning, online education and it is now called as e-learning or web-based learning. The tools provided in web allow the students to explore such kinds of skills in learning English.

Storey in Sarica and Cavus (2009) explains positive side of tools provided in web:

1. Well-designed, easy to learn, easy to use

2. Support the learning

3. Relevant and tied into the specific course structure and content 
Kress in Noytim (2010) states the attractiveness of a weblog is enhanced by its "multimodality" which includes texts (profile, reflections and feedback), colors, images, audio and video files, and hyperlinks of websites of the author's interest. Those attractiveness provide opportunities to both teachers and students, blogs help lecturer for better learner's writing performance.

Campbell in Simsek (2010) discusses the possibilities of integrating weblogs into educational contest, especially in language teaching field and mentioned about three types of blogs that are likely to be beneficial for language students, they are Lecturer blog, learner blog and class blog. In learning activity, weblogs are appropriate for the students to serve as on-line personal journal, since they can upload and link files. This is suitable for language learning activity. Language students could use a personal blog, linked to a course, as an electronic portfolio, showing development overtime. Once the students publish the blog, they have possibilities of writing for their classmates (Sarica \& Cavus, 2009). Due to the blog activity in the internet is very communicative and interactive, the students participate actually in writing process, not only as writers have they also play the role as readers.

\subsubsection{Writing activity}

\subsubsection{Writing Approach}

Activity of teaching and learning activity to students is to provide space for them to do the process as well as show the product. This becomes the approach of teaching writing, as Harmer said that in teaching writing the lecturer can focus on the product of the writing or on the product itself. When the lecturer focus on the product, it means that he/she only is only interested in the aim of the task and in the end of product. While those who focus on the process, the lecturer pays attention to the various stages that any pieces of writing goes through. The lecturer will spend the time to the flow of the stages such as pre-writing, editing, redrafting, and finally publishing. This kind of approach aims to get to the heart of the various skills that should be employed when writing.

The process of writing is complicated such is drafting, reviewing, redrafting, and writing. Thus in the editing stages the lecturer may ask the students to go back to the stage of pre-writing and re-think. Those stages are actualized by White and Arndt, they create the model of writing process in the following figure 


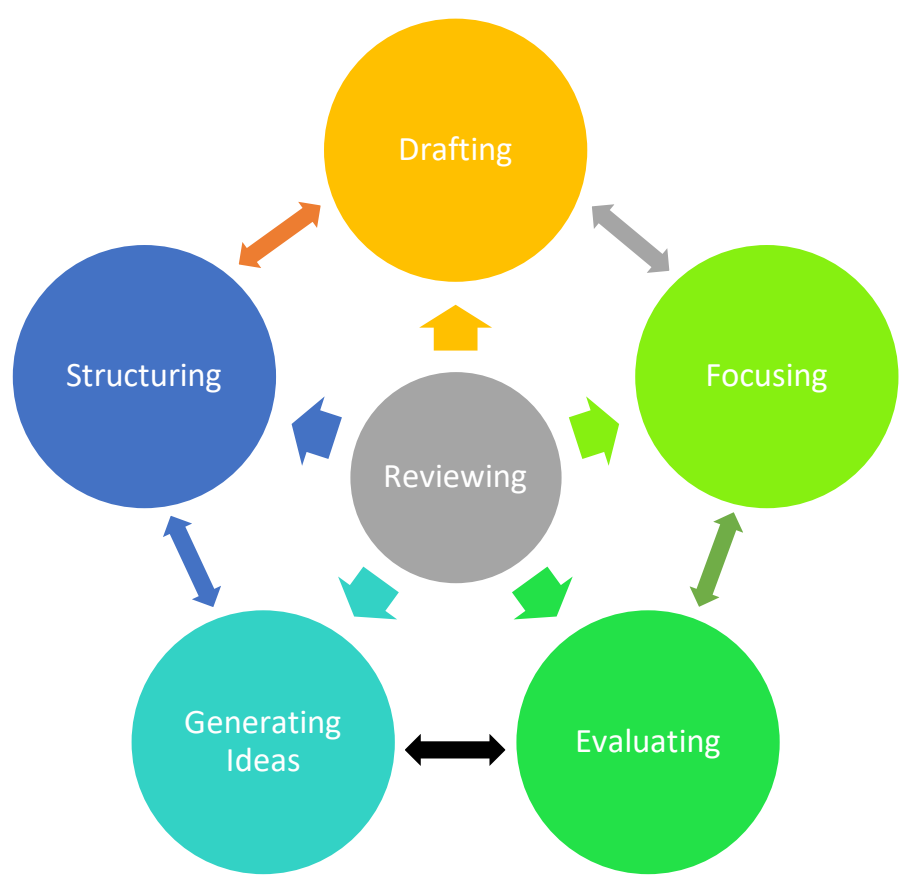

Figure 1: White and Arndt's process writing model

\subsubsection{Utilizing Technology in Writing}

With the development of technology, students of higher education is familiar with the use of notebook, laptop or computer. The process of writing using notebook, laptop or computer make the students easier to create the writing. The benefit of writing using notebook, laptop or computer is as follow:

1. A word-processing package removes the problem of poor handwriting that some students suffer from

2. A word-processing package allows the competent user to edit his or her material at great speed and with great facility

3. Spellcheckers can ease the task of achieving correct spelling

4. When the students are working in group, notebook, laptop or computer screen can sometime be far more visible to the whole group than a piece of paper

5. When the students are done with their writing, notebook, laptop or computer will ease them to connect to the internet for blog posting. They can utilize the tools from the blog as well

\subsubsection{Weblog Writing Activity}

Getting students to write is quite challenging. The focus in writing activity is on how to make the students have control over the process of writing as well as they get playfulness in its activity. This is accordance with the theory of constructivism from Harmer (2007) which claims that each person is unique in term of interpretation of the world as how the students write. It is a process of discovery, focusing of not only their final product but also the process of thinking, drafting and reviewing. Thus as the result of the invention of technology, integrating writing with computers 
provides both collaborative writing opportunities and skill development. Blog is one of developed technology that may bring students great opportunities for collaborating technology and writing activity (Ozdemir \&Aydin, 2015).

Weblog gives convenient and easy mechanism for students to produce writing product (Sidek \& Yunus, 2011). The students are supported to record and revisit their writing product, this is important part in learning writing. They also are facilitated to have higher order learning and thinking (Farmer et.al in Sidek \& Yunus, 2011). Thus the activity of weblog writing project completely gives the students opportunities to do the process of writing and challenge their higher order learning and thinking in term of English communication.

In this weblog project, the assignment is given to the students. They will have group discussion every meeting (about 10 weeks). The topic are given weekly and each week they have to produce one text posted on the weblog. They then have to give feedback to the other group's writing. This feedback is given and responded individually so he/she can see learner's individual opinion about the posts. The lecturer monitors as well as control for the posts and the feedback. In this case the interaction run between lecturer and learner.

\section{RESEARCH METHODOLOGY}

With the aim to find out and describe the experience of the students in learning writing by utilizing blog in their learning activity. Thus, Quantitative and qualitative approach is used in this research by applying descriptive analysis. Quantitative data generated by likert scale questionnaire were analyzed using descriptive statistics and frequency analysis. While for qualitative data generated from categorizing their answer in sharing their experience, concepts and thought (Cresswell (1998) as cited in Marshall and Rossman,2006).

This research took 15 students as the participant in this research. They were first semester of Mathematics Education Department students who were categorized as Non-English Major students. They took English subject as compulsory subject in semester 1 . The students attended the English class and did the blog project for six weeks. They spent 100 minutes per week to do the writing activity by utilizing blog. To collect the data, this research used Observation, Questionnaire and Brief Interview.

\section{FINDING AND DISCUSSION}

To answer the research questions of this research, here is the finding as well as the discussion. About 15 texts had been produced in this research from 18 participants who were grouped into five groups. Those texts were posted in the students' group blog. They participated the activity that in each week they have to write as well as post their writing product in the blog. They also have to comment their friends' posting. 


\section{Natalia Anggrarini ${ }^{* 1}$, Atikah Wati ${ }^{* 2}$ \\ UTILIZING BLOG IN ELT WRITING ACTIVITY TO NON-ENGLISH MAJOR UNDERGRADUATE STUDENTS OF WIRALODRA UNIVERSITY}

\section{The implementation of utilizing blog project in writing activity}

During the research, the activities were observed by taking notes in every week in the class in observation sheet. The notes focused on the interaction of the students during the project. The highlighted activities then listed as follow:

Meeting 1: When the lecturer introduced Blog project, most of the students had known even some of them also had made their own blog, but there were few students who was unfamiliar with Blog. The students were enthusiast knowing Blog project. They can search for pictures, put the video, and link to the other sources from the internet. This multimodality arouse the students' motivation to start writing in the blog. As Kress in Noytim (2010) stated in his journal that web blog provides multimodality to the students that help them in writing, so they can use picture, sounds, or even video in their blog project.

Meeting 2: The students started with their group blog, their blogs are listed below:

1. http://staycurious510852495.wordpress.com/

2. http://mathdreams.video.blog

3. https://devasirimath.wordpress.com

4. https://teachingmathdotblog.wordpress.com

5. https://matheducationdotblog.wordpress.com

In this meeting they focused on customizing their blog, there was few students who still did not understand the blog.

Meeting 3: The lecturer determined the topics for the text to the students. In this meeting they started to write. The students discussed what they were going to write in the blog, they wrote the draft, generated ideas, structured it and reviewed it before updated their writing product in their blog(White and Arndt's process writing model). The discussion run well although there were still students who did not focus on the discussion. When they finished their text, they posted their first writing product. They also started to give comment to the other group's blog. The lecturer also gave comments in the students' blogs.

Meeting 4: New topic was given, the students created new text based on the topic given. They did the stages of White and Arndt writing model. In this meeting there was an obstacle. The blogging activity was not running well since the connection to the internet. It led to the unfinished task of blogging. They continued their posting and comments after the class.

Meeting 5: New topic was given, but it seemed the topic was a little bit difficult. They also did not finish their task at the time, they continued the activity after the class.

Meeting 6: New topic was given as the last blogging activity. They finished writing as well as posting in the blog although it took time when posting the writing product because of the connection. The commenting activity was done after the class.

\section{Students' Experience of Utilizing Blog In writing activity 2.1 Questionnaires of Students' Experience in Utilizing Blog in Writing Activity}

After the meetings were conducted, the questionnaires were distributed to the students. There are five main points in the questionnaire. 
1. The purpose of writing in Blog

2. How blog help them in writing

3. Factor that influence their writing in Blog

4. Condition that support them to write more in blog

5. Blog in their opinion

Here is the recapitulation of the questionnaire:

Table 1 Students' Experience in utilizing blog in writing activity

\begin{tabular}{|c|l|c|c|}
\hline No & \multicolumn{1}{|c|}{ Points of Questionnaire } & Mean & Interpretation \\
\hline 1 & $\begin{array}{l}\text { They created writing product to share } \\
\text { ideas }\end{array}$ & 4.28 & Very High \\
\hline 2 & $\begin{array}{l}\text { They posted their writing product in } \\
\text { blog to enabling the exchange of ideas }\end{array}$ & 4.56 & Very High \\
\hline 3 & $\begin{array}{l}\text { Lack of time influences their interest in } \\
\text { Blogging }\end{array}$ & 3.78 & High \\
\hline 4 & $\begin{array}{l}\text { They will post their writing product in } \\
\text { blog if more classmate participate }\end{array}$ & 4.33 & Very High \\
\hline 5 & $\begin{array}{l}\text { Posting Writing product in Blog is useful } \\
\text { to improve their writing }\end{array}$ & 4.50 & Very High \\
\hline
\end{tabular}

\section{Blog is place to share idea}

From the figure, it can be seen that utilizing blog in writing activity seemed something new for them, the result of observation also showed that this was their first time utilizing blog in their learning activity. Only few students have been familiar with blog for different purpose. But they were enthusiasm to do the project because they can use laptop, smartphone and connect it to the internet. As this activity used technology and multimedia, they liked the activity, they did not get bored of doing the activity and this provided higher level of motivation (Amel, 2014). In this project, they have to post their writing in Blog. They were given a time to do the writing process each meeting. The drafting were done in their notes. They discussed what they will write in blog related to the topic. They searched the information related to the topic with the internet in focusing stage. After drafting and focusing in their notes, they evaluated and generated idea and structured it. Then when the draft is done, they typed it directly in the blog. They did not directly posted it but they reread their writing first, evaluate the missing point. Then, when they were sure they posted it and allowed their friend to read.

From the figure 1, the first point is to find the purpose of writing in blog. It showed that blog is place to share ideas, with mean 4.28 with very high interpretation. It means that they write their blog to their idea about something. Noytim (2010) support this finding, he reported that through blog, the students had opportunities to create and decorate their blog, create and share their profiles, express their ideas, record their memories and experiences, and exchange ideas and opinion. Blog project gave them opportunities to share their ideas. This is one example of the blog, this group wrote about cube, and they related it with their cube toy and discussed it in relation to mathematics. Although there are still many 
grammatical error but they were opened to any critics and suggestion for their post.

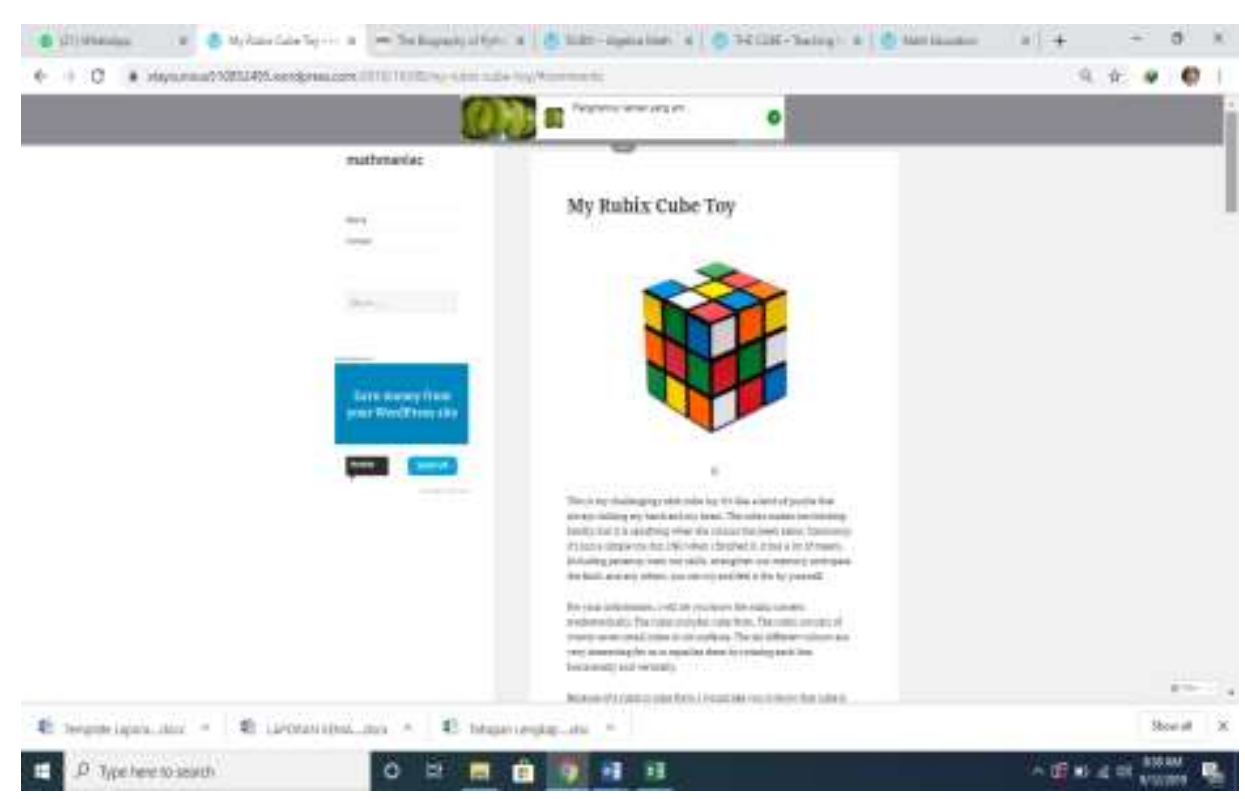

Figure 1 Blog to share Ideas

The figure above shows how the students can share the idea based on the given topic. Blog is good place to share ideas. People may write everything and share it in their blog with the purpose to tell the people about the ideas. Blog encourage them to write. Although the process of writing may take place not directly in the blog, but the concept of blog itself encourage them to create an online writing activity. This is in line with Stanley in Sidek \& Yunus (2011) who reported that blog encourage the students to write and knowing a larger audience can be reading their blogs further develops critical thingking skills.

\section{Writing in blog enables them to exchange ideas}

The second result of students experience is blog enables the students to exchange ideas. It can be seen from the chart of questionnaire that the second point is about how this blog project help them in writing. It shows that the mean is 4.65 with very high interpretation. It means that from the project they got the experience of the ideas exchange.

Posting the writing product in blog will enable the exchange of ideas from audience (Stanley in Sidek and Yunus, 2011). This exchange are realized in the comment. Since the blog is posted online, so the classmates can easily open the blog and read their friends writing product. Thus, blog provide not only writing activity but also reading activity in a unique style form of expression Kennedy in Akcay \& Arslan (2010). The students read respond the writing product and express it by writing their opinion or ideas in comment column. 


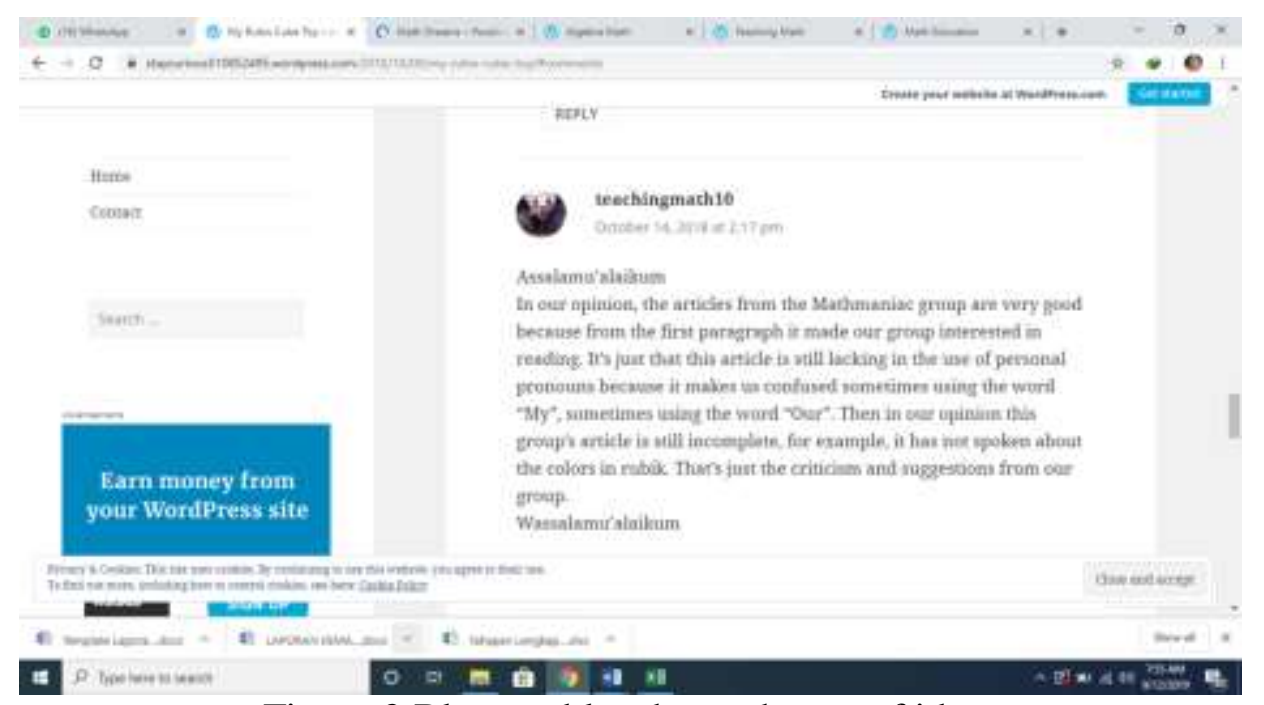

Figure 2 Blog enables the exchange of ideas

\section{Time Allocation influences the students' interest of writing in Blog}

The third point of questionnaires is factors that mostly influence the students' interest of writing in blog. The factor is the time. The figure 1 shows that it took 3 . 78 mean with high interpretation. It means that the lack of the time becomes the highest factor that influence their interest of writing in Blog. They need more time to get maximal result of their writing product. Since in this research, the time is limited in only 100 minutes of each meeting, the students felt it was not enough. It is challenges in doing the project of writing in blog. As Mansor (2010) reported in his research, that one of challenges in using journal in writing activity is time. The student need longer time to finish writing in blog. This also means that the lecturer need extra workload to checking the students blog, the comment and feedback. And It seemed really affect to their interest. From short interview S4 said that the time was not enough, we were in hurry to finish the test to post. And the teacher gave less comment to our blog so maybe we felt unmotivated to write in the same time we feld nervous if the lecturer comment our blog. Then, blog project is better to have more than 100 minutes per meeting with the lecturer constantly check and comment the students' blog.

\section{Larger class is needed in the Blog project}

The fourth point of questionnaire is the involvement of students. The larger participants the better. This point gained 4.33 mean, with very high interpretation. It means that this activity need more students to involve. Since the research is done in small class, this influence to what they got from the activity. Blog provide larger audience to involve but because the project was done in small class the audience that is expected to give more comment is less. So the students felt that this was become one of the weakness of the project. Although web-blog is considered as interesting way in writing activity but the participants of the project also determine the students' motivation. The larger audience allow the exchange or ideas (Sidek and Yunus, 2011), thus the blog project will get better response and give better experience if it is done to larger class. 


\section{Writing in blog help the students to improve their writing}

The fifth point of questionnaire cover the use of blog in writing activity. The students agree that blog is useful in improving their writing. It took 4.50 mean with very high interpretation. The students felt that Blog help them to improve their writing. And respond creatively by reading their writing and classmate's. Their comments in their classmate's blog were about evaluating the writing product.

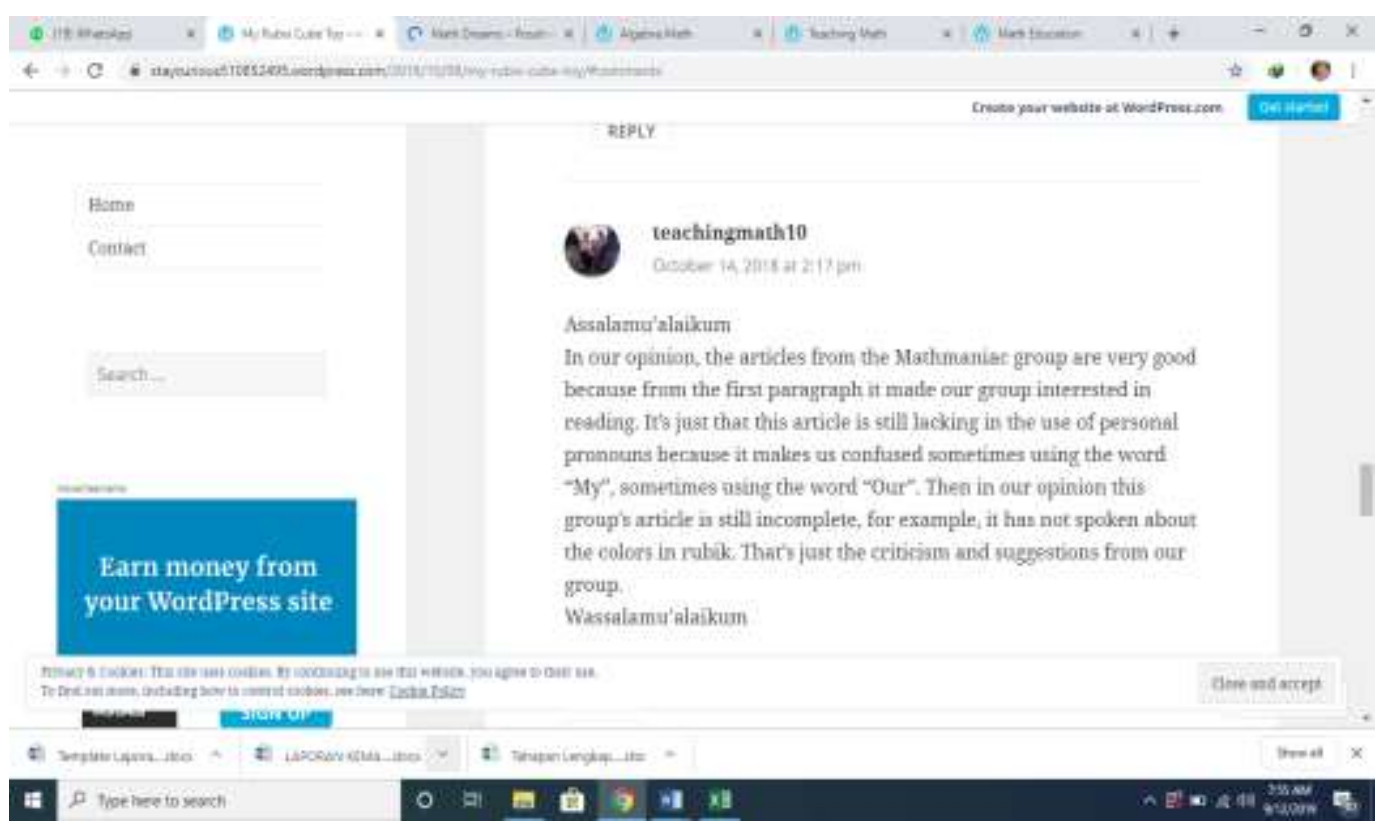

Figure 3 evaluating article

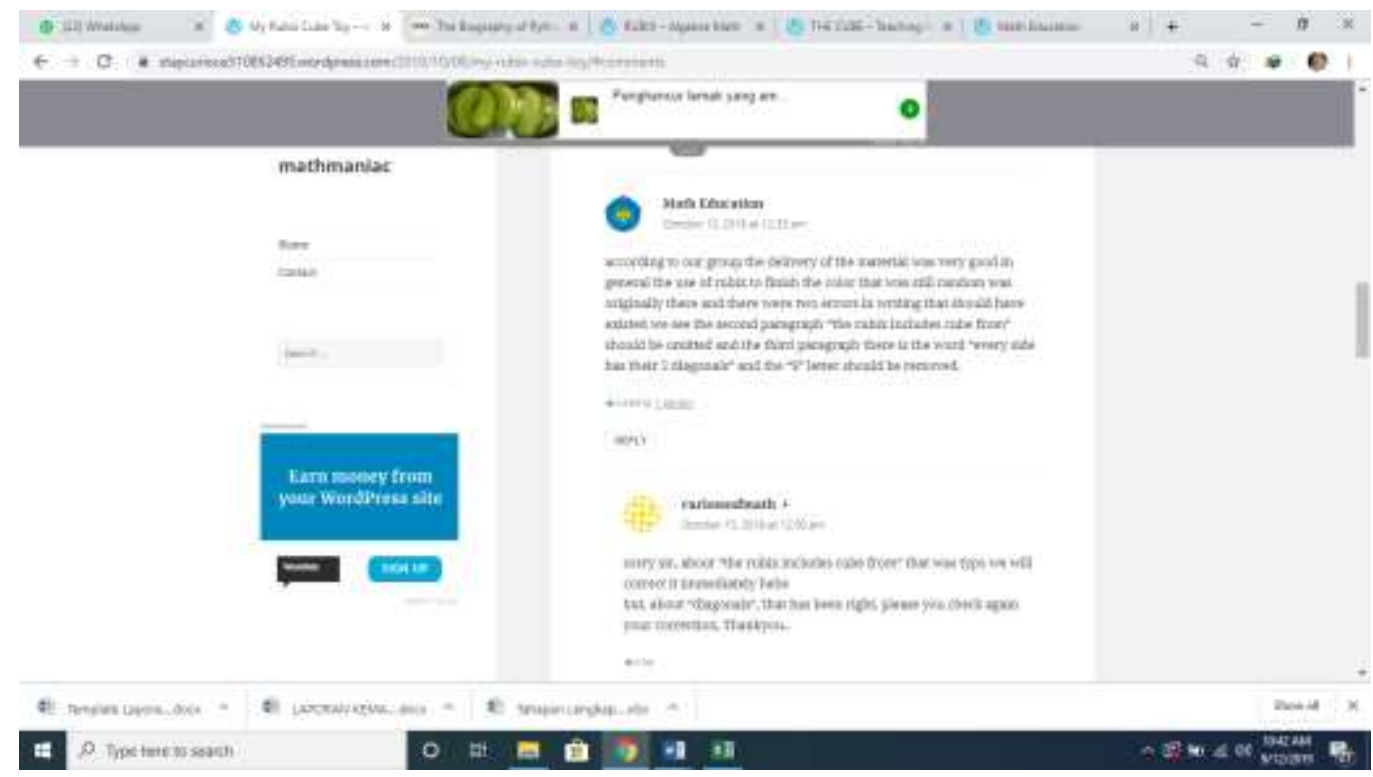

Figure 4 evaluating Spelling 


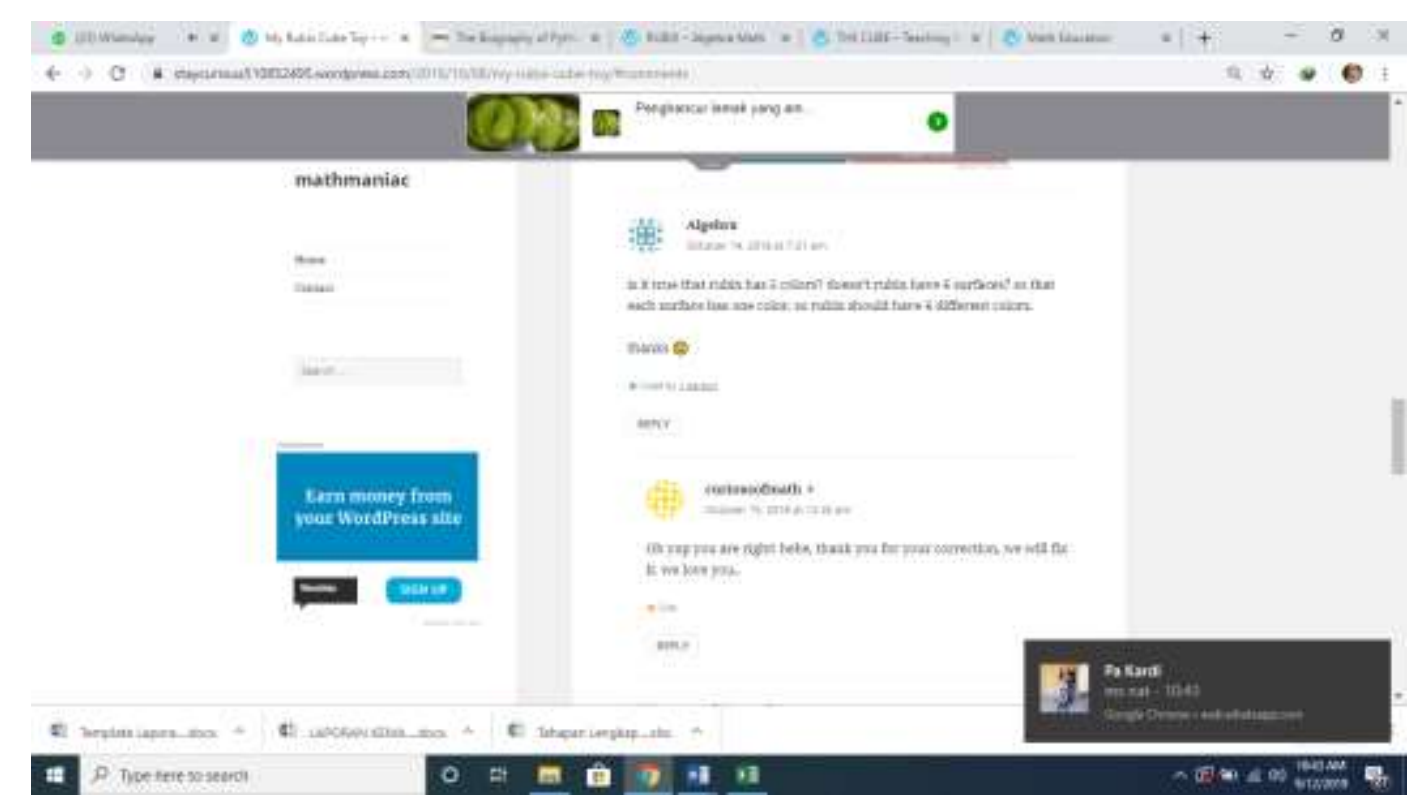

Figure 5 improve critical thinking

Blog provide space to give comment, here the students were freely to express their opinion related to the posts. The comments in the pictures above showed that they can analyze the writing products from the other friends' posts. It was about the spelling and the articles. Based on Noytim (2010), Blogs give opportunity and freedom for self-expression in English, writing for both local and global audience, fostering creative, analytical thinking skills, creating social interaction and good relationships between the writer and readers, and supporting the learning communities. It can be seen from the figures above that the communications built in the comments show the interaction between the reader and the writer. Picman in Sarica, \& Cavus (2009) supported that blogging becomes communicative and interactive when the participants assume multiple roles in the writing process, as writers who writes and posts, as readers/reviewers who respond to other writers' posts, and as writer and readers who, returning to their own posts, react to criticize of their own posts. Readers in turn can comment on what they read, although blogs can be placed in secured environments as well.

Blog also is consider as a learning media that arouse critical thinking, where the students can critically think about the post. From figure 2.5 we can see that the reader tried to critize the writer related to the content. It showed that blog provides the space for the students to improve their critical thinking. Duffy in Akcay \& Arslan (2010) supported that within the structure of a blog, students can demonstrate critical thinking, and creative risk and make sophisticated use of language and design elements.

\section{The students' Respond toward Utilizing Blog in Writing Activity 3.1 Students' Personal Comments (Brief Interview)}

After they completing the questionnaires they got brief interview to confirm their answer in questionnaires. Their responses about utilizing blog in writing activity are summarized in the chart below. 


\section{Positive Response}

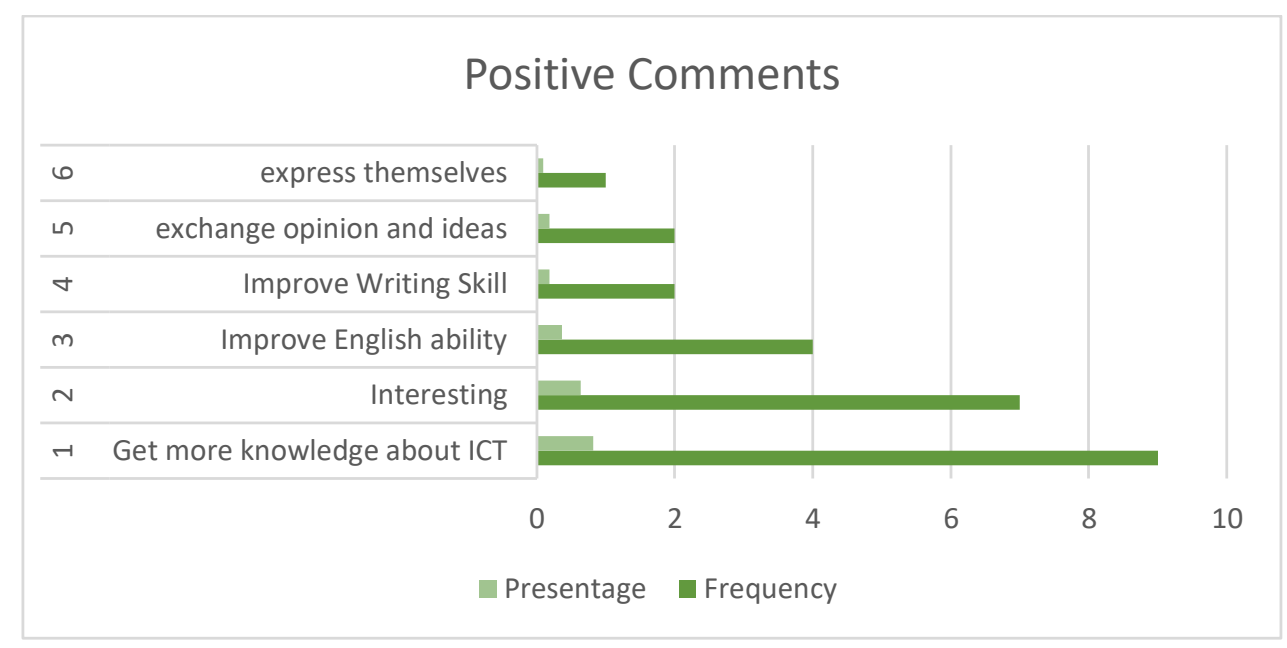

Figure 6. Bar Chart of Positive Personal Comments

From the chart we can see that writing activity by utilizing blog gave them experience in getting more knowledge of ICT with $81.82 \%$. Through the activity of blogging, the students felt that it broaden their knowledge through the internet, especially the blog itself. They can look for the information or sources needed for their blog directly from the internet. It is supported by Belmekki \& Ibrahimi(2014) who stated that internet in this case web-based learning help the learners broaden their knowledge through looking for information especially those related to their courses.

\section{Negative Response}

While for the negative personal comments, here is the chart.

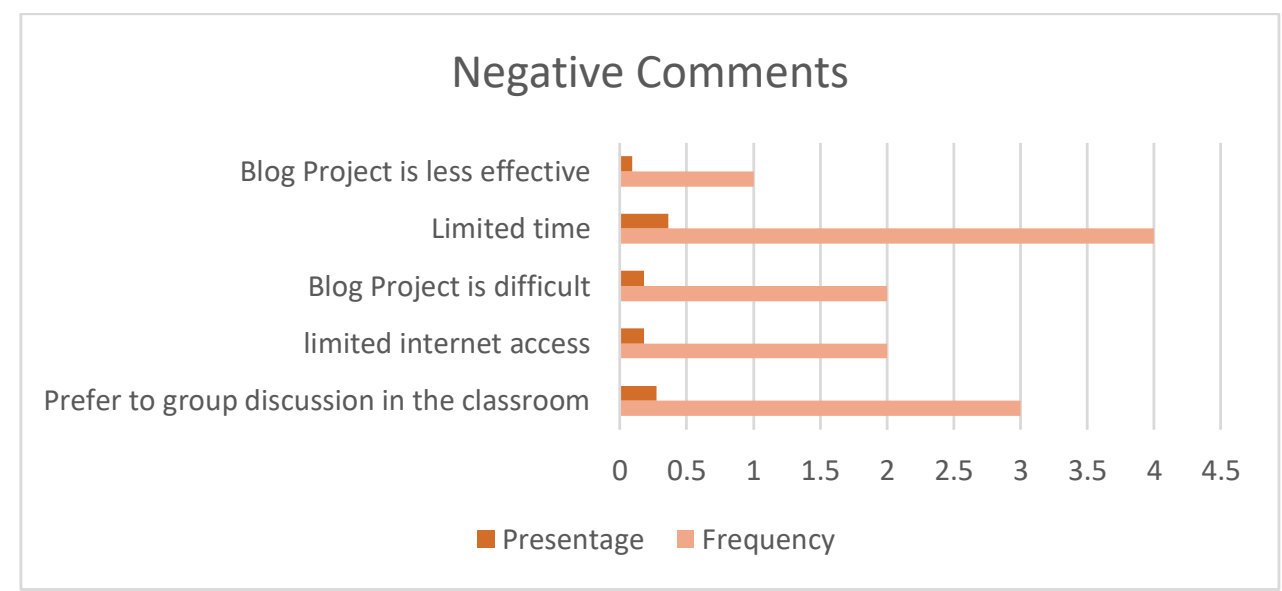

Figure 7. Bar chart of negative personal comment

From the chart we can see that the students complaining the limited time for blog project with the percentage $36.36 \%$. The activity of writing by utilizing blog needs longer time to take. Since the research was done in 100 minutes per meeting, the students felt it was not enough to create writing product in blog 
maximally. Thrope in Mansor(2010)supported that using blog in teaching and learning activity demands longer time for both the teacher and the students. However, from the interview, it can be seen that mostly students respond positively toward the utilizing blog in writing activity. It supported by Amel (2014) that web-based learning, in this case the Blog is mostly responded positively by the students.

\section{CONCLUSION AND SUGGESTION}

From the finding of the result, the implementation of blog project to non-English major students' needs comprehensive preparation in term of creating the blog, the time allocation, as well as the internet connection. Blog gave the students a place to share their ideas, exchange ideas, and improve their English as well as their writing ability. Utilizing blog in writing activity also gave them more knowledge about ICT especially in blogging. From this research, the researchers also find some points that should be considered by the teachers. First, to do writing activity by utilizing blog the teacher should provide longer time and guide them intensively inside and outside the class. Second, it is better to do blog project in larger class. Larger class provides more students to participate especially in giving feedback to the posts (interaction in the blog).

\section{ACKNOWLEDGMENT}

This research was supported by the Research Fund provided by Directorat of Research and Community Service, Directorate General for Research and Development, Ministry of Research, Technology and Higher Education. In accordance with the Research Contract for Fiscal Year 2019. The research scheme was "Penelitian Dosen Pemula"

\section{REFERENCES}

Akcay, A., \& Arslan, A. (2010). The Using of Blog in Turkish Education. Procedia Social and Behavioral Sciences, 1195-1199.

Amel, B. (2014). Students' Insights and Experiences of Web-Based Learning Support: The Case of Second Year Students of University of Batna Algeria. Arab World English Journal, 71-78.

Belmekki, N., \& Ibrahimi, E. O. (2014). The Integration of The New Technology at The Moroccan Universities. Arab World English Journal, 427-442.

Cresswell, John W. (1998). Qualitative Inquiry and Research Design, Choosing Among Five Tradition. California: SagePublication.

Deng, L., \& Yuen, A. H. (2012). Understanding Students' Perceptions and Motivation Towards Academic Blog; An Exploratory Study. Australian Journal of Education Technology, 48-66. 
Akcay, A., \& Arslan, A. (2010). The Using of Blog in Turkish Education. Procedia Social and Behavioral Sciences, 1195-1199.

Amel, B. (2014). Students' Insights and Experiences of Web-Based Learning Support: The Case of Second Year Students of University of Batna Algeria. Arab World English Journal, 71-78.

Belmekki, N., \& Ibrahimi, E. O. (2014). The Integration of The New Technology at The Moroccan Universities. Arab World English Journal, 427-442.

Deng, L., \& Yuen, A. H. (2012). Understanding Students' Perceptions and Motivation Towards Academic Blog; An Exploratory Study. Australian Journal of Education Technology, 48-66.

Harmer, J. (2001). How To Teach English. Edinburgh: Longman.

Harmer, J. (2004). How to Teach Writing. England: Longman.

Harmer, J. (2007). The Practice of English Language Teaching 3rd Edition. England: Longman.

Ince, M. (2014). The Investigation of Intructors's Views on Using Technology in English Language Teaching. Procedia Social and Behavioral Sciences, 670674.

Kamberi, L. (2015). Using Blogs in EFL Teaching - A Case Study of Macedonia. Procedia Social and Behavioral Sciences, 957-962.

Mansor, A. Z. (2010). Reflective Learning Journal Using Blog. Procedia Social and Behavioral Sciences, 507-516.

Marshall, C., \& Rossman, G. B. (2006). Designing Qualitative Research. London: Sage .

Noytim, U. (2010). Weblogs Enhancing EFL Students' English Language Learning. Procedia Social and Behavioral Sciences, 1127-1132.

Ozdemir, E., \& Aydin, S. (2015). The Effect of Blogging on EFL Writing Achievement. Procedia Social and Behavioral Sciences, 372-380.

Ozkan, M. (2014). Wikis and Blogs in Foreign Language Learning from Perspectives of Students. Procedia Social and Behavioral Sciences, 672678.

Sarica, G. N., \& Cavus, N. (2009). New Trends in 21st Century English Learning. Procedia Social and Behavioral Sciences, 439-445.

Sidek, E. A., \& Yunus, M. M. (2011). Students' Experience on Using Blog as Learning Journals. Procedia Social and Behavioral Sciences, 135-143. 
WEJ, Vol 3 No 2 September 2019

Simsek, O. (2010). The effect of Weblog (Blog) in Students' Writing Performance. Procedia Social and Behavioral Sciences, 953-958.

Tajuddin, N. e. (2011). Investigating Students' Acceptance Towards Blog. Procedia Social and Behavioral Sciences, 444-453.

Woodside, A. G. (2010). Case Study Research. Bingley: Emerald. 